\title{
Determination of the Effect of the System of Rice Intensification (SRI) on Rice Yields and Water Saving in Mwea Irrigation Scheme, Kenya
}

\author{
Kepha G. Omwenga, Bancy M. Mati, Patrick G. Home \\ Biomechanical and Environmental Engineering Department, Jomo Kenyatta University of Agriculture and \\ Technology, Nairobi, Kenya \\ Email: beed@jkuat.ac.ke
}

Received 11 April 2014; revised 8 May 2014; accepted 2 June 2014

Copyright (C) 2014 by authors and Scientific Research Publishing Inc.

This work is licensed under the Creative Commons Attribution International License (CC BY). http://creativecommons.org/licenses/by/4.0/

c) (i) Open Access

\begin{abstract}
Irrigated rice cultivation has long been associated with large amounts of water. Currently convectional rice production is faced with major challenges of water shortage as a result of increasing population sharing the same water resources, as well as global environmental changes. The System of Rice Intensification (SRI), as opposed to conventional rice production, involves alternate wetting and drying (AWD) of rice fields. The objective of this study was to determine the optimum drying days period of paddy fields that has a positive effect on rice yields and the corresponding water saving. The experimental design used was randomized complete block design (RCBD). Four treatments and the conventional rice irrigation method were used. The treatments were the dry days allowed after draining the paddy under SRI before flooding again. These were set as $0,4,8$, 12 and 16 day-intervals. Yield parameters were monitored during the growth period of the crop where a number of tillers, panicles, panicle length and panicle filling were monitored. Amount of water utilized for crop growth for each treatment was measured. Average yield and corresponding water saving were determined for each treatment. The results obtained show that the 8 days drying period gave the highest yield of 7.13 tons/ha compared with the conventional method of growing rice which gave a yield of 4.87 tons/ha. This was an increase of $46.4 \%$ above the conventional method of growing rice. Water saving associated with this drying regime was $32.4 \%$. This was taken as evidence that SRI improved yields with reduction in water use.
\end{abstract}

\section{Keywords}

Alternate Wetting and Drying, System of Rice Intensification, Water Saving, Rice Yield

How to cite this paper: Omwenga, K.G., Mati, B.M. and Home, P.G. (2014) Determination of the Effect of the System of Rice Intensification (SRI) on Rice Yields and Water Saving in Mwea Irrigation Scheme, Kenya. Journal of Water Resource and Protection, 6, 895-901. http://dx.doi.org/10.4236/jwarp.2014.610084 


\section{Introduction}

Water is the most important component of sustainable rice production in traditional rice growing areas of the world. The traditional method of growing rice has been continuously flooded conditions during vegetative growth of the crop with draining of the water during grain ripening stage. This method of continuous flooding is practiced in all the rice growing schemes in Kenya. This is because it is believed rice is an aquatic plant or at least a hydrophilic one [1]. This method is associated with high water use because of the continuous flooding of rice paddies and it is occasioned by losses through seepage, percolation and evaporation. The quantity of irrigation water used for example in Mwea Irrigation Scheme (MIS) has positive but insignificant effect on rice output, probably implying overuse of water [2].

With the decreasing availability of water for use in agriculture due to climate change and increased competition from other players like the industrial and urban sectors, water use in rice production systems has to be reduced in order to maintain production. At the same time, output per unit volume of irrigation water has to be increased so as to meet the increasing demand for rice in the world. There are various methods which have been used in reducing water use in rice production. One of the most tried methods is alternate wetting and drying (AWD) of rice paddy fields.

In a research done in lowland irrigated lands in Asia [3], alternate submergence-non submerged systems reduced water use up to $15 \%$ without affecting yields when the shallow ground water stays within about $0-30 \mathrm{~cm}$. Another method of saving water use in rice production is saturated soil culture [4]. The soil is kept at around saturation part of or the entire growing season. But this resulted in lower yields than the traditional method of continuous flooding although the differences in yields were not statistically significant. It reduced the water input by $31 \%-58 \%$.

But these conclusions cannot be generalized as the AWD irrigation methods adopted in given areas may not transfer to other areas because of difference in climatic, soil and topographic conditions. Therefore, there is a need for area specific research to come up with recommendations for the best regime for AWD suited for such areas.

The system of rice intensification (SRI) is an AWD method that has been tried in a number of countries in the world. It is a methodology for increasing the productivity of irrigated rice by changing the management of plants, soil, water and nutrients. It involves transplanting young seedlings (8 days old) and planting singly at a wider spacing $(20 \mathrm{~cm} \times 20 \mathrm{~cm}-40 \mathrm{~cm} \times 40 \mathrm{~cm}$ ). Compost is preferred for nutrients supply and the paddy is dried and wetted alternately. This method has been associated with water saving, because of alternate wetting and drying of rice paddies during the vegetative growth of the crop as opposed to the conventional continuous flooding. There are reported cases of increased yields in a number of countries where it has been tried [5].

\section{Methodology}

This study was carried out at the Mwea Irrigation Agricultural Development (MIAD) research centre at Mwea Irrigation Scheme (MIS) in Wamumu sub-location, Kirinyaga County of Kenya. The experimental design used was randomized complete block design (RCBD). Four treatments under SRI and conventional rice irrigation methods were used in three blocks each with five plots. Plots used were of size $3 \mathrm{~m} \times 3 \mathrm{~m}$. The variety of rice planted was Basmati 370.

For SRI plots, seedlings raised in a nursery were transplanted singly after 8 days when 2 leaves had developed. Spacing used for the seedlings was $20 \mathrm{~cm} \times 20 \mathrm{~cm}$. For conventional rice irrigation, 21 days old seedlings were randomly transplanted with 3 - 5 seedlings per hill at approximately $10 \mathrm{~cm} \times 10 \mathrm{~cm}$. After a week, when the SRI plots had dried, they were flooded to a depth of $3 \mathrm{~cm}$ and drained after two days. Flooding and draining of the plots was repeated for the four different treatments. The different treatments used were: flooding 4 days after draining (T1), flooding 8 days after draining (T2), flooding 12 days after draining (T3) and flooding 16 days after draining (T4). T5 was the control which comprised the conventional practice of growing rice in MIS which involves continuous flooding.

The parameters measured for each drying regime were the number of tillers, number of productive tillers (with panicles), length of panicles and percentage of grain filling. Yield for each drying regime was then determined. The yields were subjected to analysis of variance to determine their statistical significance.

In determining the water used for each treatment, the amount of water added and drained for each drying regime was measured using a 1 inch Parshall flume. This was installed at each plot inlet when adding water into the plot and at each plot outlet when draining the plot. The initial height of water at the inlet of the flume was 
recorded. Water was then allowed into the plot through the flume throat. Time taken to flood the plot to the $3 \mathrm{~cm}$ depth was recorded. Final height of water on the converging side was recorded at the end of the flooding process. This was repeated during draining where the initial height of water on the converging side of the Parshall flume and the final height after draining were recorded

The amount of water added into or drained out of each plot was calculated using the formula (Equation (1)):

$$
Q=C H^{1.55}
$$

where

$Q=$ Flow rate of water into or out of the plot (cubic feet $/ \mathrm{sec}$ );

$C=$ Constant depending on the throat of the Parshall flume (0.338 for 1 inch throat used in the study);

$H=$ Average of initial and final height of water in the converging zone of flume (feet).

The difference between the flooded and drained water was the amount utilized in the plot for crop growth. The water utilized for each drying regime was then compared to that used in the conventional method of growing rice to determine the water saving.

\section{Results}

SRI on average produced more tillers and panicles (55 and 51 respectively) compared to the conventional method of growing rice (25 and 21) as shown in Figure 1.

These were found to be statistically significant at $95 \%$ significance level. The calculated significance value $(<0.001)$ for both cases is less than 0.05. This is shown in Table 1 and Table 2 .

The average panicle length was longer in SRI $(25.4 \mathrm{~cm})$ compared to the conventional method $(22.6 \mathrm{~cm})$ Figure 2 shows the variation of panicle length for conventional irrigation and SRI.

The differences in panicle length were found to be statistically significant at 95\% confidence level. The calculated significance value $(<0.001)$ is less than 0.05 as shown in Table 3.

SRI recorded a higher average percentage of grain filling (81.5\%) than conventional method $(75.1 \%)$ as illustrated in Table 4.

But the percentage grain filling is not statistically significant at $95 \%$ significance level. The calculated significance value (0.663) is more than 0.05 . This is shown in Table 5.

On average yields, the 8 days drying regime gave the highest yield of 7.13 tons/ha while conventional method yielded 4.87 tons/ha. This is an increase of $46.4 \%$ above conventional method of growing rice. This is shown in Table 6.

The average yields are statistically significant at 95\% significance level. The calculated significant value (0.001) is less than 0.05 (Table 7).

The 12 days drying regime yielded slightly less than the 8 days' drying regime although the difference was not statistically significant. A comparison between means of yields conducted showed the significance value for the test of the contrast (0.053) to be larger than 0.05 (Table 8).

The water saving realized for the 8 and the 12 days' drying regimes was $32 \%$ and $42 \%$ respectively as shown in Table 9.

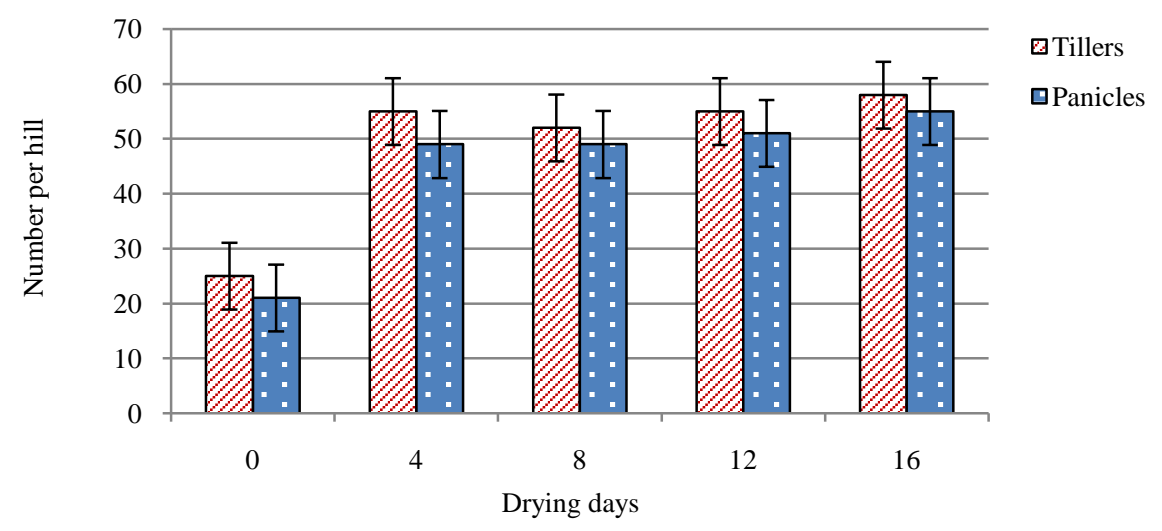

Figure 1. Average tillers and panicles. 


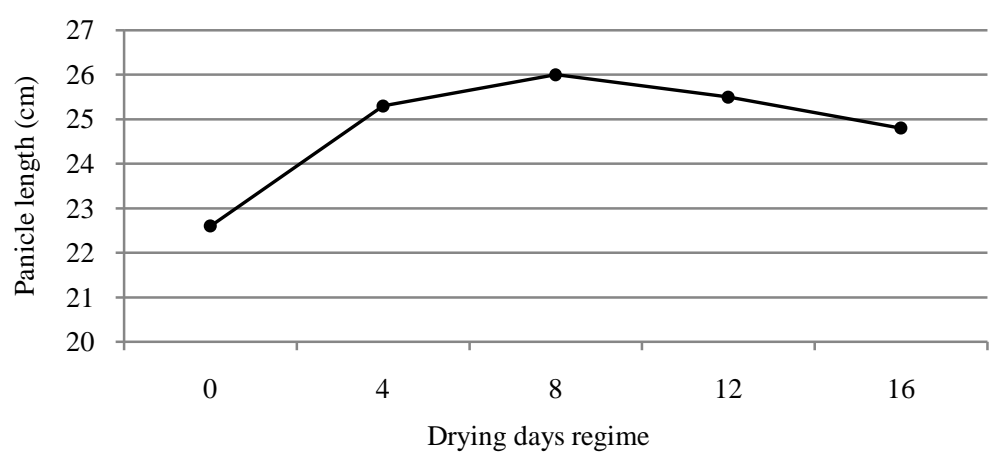

Figure 2. Average panicle lengths.

Table 1. ANOVA for tillers.

\begin{tabular}{cccccc}
\hline & Sum of Squares & df & Mean Square & F & Sig. \\
\hline Between Groups & 2209.733 & 4 & 552.433 & 19.316 & 0.000 \\
Within Groups & 286.000 & 10 & 28.600 & & \\
Total & 2495.733 & 14 & & & \\
\hline
\end{tabular}

Table 2. ANOVA for panicles.

\begin{tabular}{cccccc}
\hline & Sum of Squares & df & Mean Square & F & Sig. \\
\hline Between Groups & 2149.733 & 4 & 537.433 & 17.875 & 0.000 \\
Within Groups & 300.667 & 10 & 30.067 & & \\
Total & 2450.400 & 14 & & & \\
\hline
\end{tabular}

Table 3. ANOVA for panicle length.

\begin{tabular}{cccccc}
\hline & Sum of Squares & df & Mean Square & F & Sig. \\
\hline Between Groups & 20.329 & 4 & 5.082 & 27.823 & 0.000 \\
Within Groups & 1.827 & 10 & 0.183 & & \\
Total & 22.156 & 14 & & & \\
\hline
\end{tabular}

Table 4. Percent grain filling.

\begin{tabular}{ccc} 
Drying Days & Percent Grain Filling & \% Deviation from Conventional Irrigation \\
\hline 0 & 75.1 & - \\
4 & 82.6 & 7.5 \\
8 & 80.9 & 5.8 \\
12 & 80.3 & 5.2 \\
16 & 82.2 & 7.1 \\
\hline
\end{tabular}

Table 5. ANOVA for grain filling in main crop.

\begin{tabular}{cccccc}
\hline & Sum of Squares & df & Mean Square & F & Sig. \\
\hline Between Groups & 110.837 & 4 & 27.709 & 0.612 & 0.663 \\
Within Groups & 452.560 & 10 & 45.256 & & \\
Total & 563.397 & 14 & & & \\
\hline
\end{tabular}


Table 6. Average yields.

\begin{tabular}{cccc}
\hline Drying Days & Yield (t/ha) & Increase above Conventional Irrigation(t/ha) & Percent Increase \\
\hline 0 & 4.87 & - & - \\
4 & 5.52 & 0.65 & 13.4 \\
8 & 7.13 & 2.26 & 46.4 \\
12 & 6.17 & 1.3 & 26.6 \\
16 & 4.59 & -0.28 & -5.85 \\
\hline
\end{tabular}

Table 7. ANOVA for yield in main crop.

\begin{tabular}{cccccc}
\hline & Sum of Squares & df & Mean Squares & F & Sig. \\
\hline Between Groups & 12.624 & 4 & 3.156 & 10.874 & 0.001 \\
Within Groups & 2.902 & 10 & 0.290 & & \\
Total & 15.526 & 14 & & & \\
\hline
\end{tabular}

\begin{tabular}{ccccccccc}
\multicolumn{7}{l}{ Table 8. Contrast test for 8 and 12 days drying regimes. } \\
\hline & Contrast & $\begin{array}{c}\text { Value of } \\
\text { Contrast }\end{array}$ & Std. Error & t & df & $\begin{array}{c}\text { Sig. } \\
\text { (2-tailed) }\end{array}$ \\
\hline $\begin{array}{c}\text { Yield } \\
\text { t/ha }\end{array}$ & $\begin{array}{c}\text { Assume Equal Variances } \\
\text { Does Not Assume Equal } \\
\text { Variances }\end{array}$ & 1 & 0.9633 & 0.43986 & 2.190 & 10 & 0.053 \\
\hline
\end{tabular}

\begin{tabular}{|c|c|c|}
\hline Drying Days & Irrigation Water Use $\left(\times 10^{3} \mathrm{~m}^{3} / \mathrm{ha}\right)$ & Percent Irrigation Water Saving \\
\hline 0 & 12.0 & - \\
\hline 4 & 8.71 & 27 \\
\hline 8 & 8.13 & 32 \\
\hline 12 & 6.93 & 42 \\
\hline 16 & 4.64 & 58 \\
\hline
\end{tabular}

Average water productivity per unit volume of water for rice yield under conventional rice production and SRI is $0.4 \mathrm{~kg} / \mathrm{m}^{3}$ and $0.84 \mathrm{~kg} / \mathrm{m}^{3}$ respectively.

\section{Discussion}

Productivity of rice is a function of many parameters. Among the parameters which influence the yields are the number of tillers produced, the number of panicles formed, panicle length and percentage grain filling. There is a significant effect on these parameters brought about by SRI. The difference between SRI and conventional method of growing rice is evident in the number of tillers per hill and the number of panicles formed. But the different drying regimes had different effects on the other yield parameters. This in turn affected the individual yields for the drying regimes.

The better performance of the four, eight and twelve days drying regimes can be attributed to higher average number of tillers and panicles formed and longer average panicle length compared to the conventional irrigation method.

The number of tillers produced under SRI was more than those produced under conventional practice of growing rice. This is because the seedlings used in SRI were planted at an early age and tillers start developing as early as 14 days. The synergetic effect of young seedlings is seen in tiller formation, panicle length and percentage grain filling. These lead to higher yields [6]. Transplanting of young seedlings induces higher tiller production at an early stage. With increasing transplanting age of rice seedlings, emergence of tillers is delayed [7].

Seedlings under SRI are transplanted singly and spaced widely as opposed to conventional method of growing 
rice where they were transplanted 3 - 5 per hill at close spacing. This implied that there was no competition for nutrients between the seedlings under SRI. Wider spacing in SRI means that each plant had a wider area where it would draw it's nutrients from leading to more tillers, panicle length and number of filled grains [6]. This has a direct implication on the increased rice yield for SRI [8].

Wetting and drying of rice paddies has the beneficial effect of enhancing root growth. The rewetting facilitates nitrogen mineralization and this is made available to the plant for growth [8].

The main attracting attribute of SRI to farmers is what they will expect, in terms of yields, from adopting it. Generally SRI posted higher yields than conventional method of growing rice except for the sixteen days drying regime for the main crop. If water deficit is properly controlled especially during grain filling stage of rice, it enhances whole-plant senescence. This facilitates remobilization of carbon reserves, accelerate grain filling and increase grain yield [9].

From the comparison between means of yields conducted, since there are no statistically significant difference in yield between the 8 and 12 days drying regime, the two drying regimes can be used for the study area. This helps to support the notion that rice is not an aquatic plant but can be considered hydrophilic [1].

The lower yields in the 16 days drying regime for the main crop can be attributed to water stress suffered by the crop because of the prolonged drying period. Water stress imposed during the reproductive period can lead to reduced grain yield [10]. These moisture sensitive periods are flowering and head development stages [11]. Decrease in yield can be attributed to decrease in number of filled grains per panicle. This is manifested in the good average panicle length and low percentage grain filling. Conventional method performed marginally better than the 16 days drying regime because of presence of water during grain formation and filling.

Challenges facing rice production are to save on water use, increase water productivity and produce more rice with less water. The water saving associated with highest yields is $32.3 \%$. This is for the eight days drying regime. Since the difference in yields between the eight and twelve days drying regimes are not statistically significant, the water saving for twelve drying days of $42.2 \%$ is also applicable.

The saving in irrigation water use under SRI is because of the remarked reduction in percolation, seepage and evaporation because of draining standing water from the plots. This saving should be sufficient reason for governments, international agencies and environmental organizations to promote the adoption of SRI [12] as water for agriculture use is becoming more and more limited.

\section{Conclusion}

The system of rice intensification is a rice production methodology that can be used by farmers to increase the water productivity in rice growing schemes. Drying of rice paddies for between 4 and 12 days under SRI has positive impacts on rice yields. This results in water saving of between $27 \%$ and $42 \%$. This saving has an implication on increasing area under rice irrigation.

\section{Recommendations}

The system of rice intensification should be adopted in MIS as a means of increasing water productivity to address the diminishing water resources. A drying regime of eight days is ideal for MIS to help increase farmers' yield. But drying paddies for between 4 - 12 days can improve rice yields. Further research should be done to determine the effect of spacing on rice production for the 8 and 12 days drying regimes. Also studies on direct seeding should be done to determine the effect on rice yield.

\section{References}

[1] Satyanarayana, A., Thiyagarajan, T.M. and Uphoff, N. (2007) Opportunities for Water Saving with Higher Yield from the System of Rice Intensification. Irrigation Science, 25, 99-115. http://dx.doi.org/10.1007/s00271-006-0038-8

[2] Obiero, O.B.P. (2011) Analysis of Economic Efficiency of Irrigation Water-Use in Mwea Irrigation Scheme, Kirinyaga District, Kenya. Kenyatta University, Nairobi Kenya.

[3] Belder, P., Bouman, B.A.M., Cabangon, R., Lu, G., Qualing, E.J.P., Li, Y.H., Spiertz, J.H.J. and Tuong, T.P. (2004) Effect of Water-Saving Irrigation on Rice Yield and Water Use in Typical Lowland Conditions in Asia. Agricultural Water Management, 65, 193-210. http://dx.doi.org/10.1016/j.agwat.2003.09.002

[4] Tabbal, D.F, Bouman, B.A.M., Bhuiyan, S.I., Sibayan, E.B. and Sattar, M.A. (2002) On-Farm Strategies for Reducing Water Input in Irrigated Rice; Case Studies in the Philippines. Agricultural Water Management, 56, 93-112. 
http://dx.doi.org/10.1016/S0378-3774(02)00007-0

[5] Uphoff, N. (2005) Features of SRI Apart from Increase in Yields. CIIFAD, New York.

[6] Chapagain, T. and Yamaji, E. (2010) The Effect of Irrigation Method, Age of Seedling and Spacing on Crop Performance, Productivity and Water-Wise Rice Production in Japan. Paddy and Water Environment Journal, 8, 81-90. http://dx.doi.org/10.1007/s10333-009-0187-5

[7] Estela, P., Tubana, B., Bertheloot, J. and Lafarge, T. (2004) Impact of Early Transplanting on Tillering and Grain Yield in Irrigated Rice. 4th International Crop Science Congress, Brisbane, 26 September 2004.

[8] Ceasey, M., Reid, W.S., Fernandes, E.C.M. and Uphoff, N.T. (2006). The Effects of Repeated Soil Wetting and Drying on Lowland Rice Yield with System of Rice Intensification (SRI) Methods. International Journal of Agricultural Sustainability, 4, 5-14.

[9] Yang, J.C., Zhang, J.H., Wang, Z.G., Liu, L.J. and Zhu, Q.S. (2001) Hormonal Changes in the Grains of Rice Subjected to Water Stress during Grain Filling. Plant Physiology, 127, 315-323. http://dx.doi.org/10.1104/pp.127.1.315

[10] Lilley, J.M. and Fukai, S. (1994) Effect of Timing and Severity of Water Deficit on Four Diverse Rice Cultivars III. Phenological Development, Crop Growth and Grain Yield. Field Crops Research, 37, 225-234. http://dx.doi.org/10.1016/0378-4290(94)90101-5

[11] Halil, S. and Neemi, B. (1999) The Effect of Water Stress on Grain and Total Biological Yield and Harvest Index in Rice (Oryzae sativae L.). In: Chataigner, J., Ed., Future of Water Management for Rice in Mediterranean Climate Areas: Proceedings of the Workshops, CIHEAM, Montpellier, 61-68.

[12] Uphoff, N. (2006) The System of Rice Intensification (SRI) as a Methodology for Reducing Water Requirements in Irrigated Rice Production. CIIFAD, New York. 
Scientific Research Publishing (SCIRP) is one of the largest Open Access journal publishers. It is currently publishing more than 200 open access, online, peer-reviewed journals covering a wide range of academic disciplines. SCIRP serves the worldwide academic communities and contributes to the progress and application of science with its publication.

Other selected journals from SCIRP are listed as below. Submit your manuscript to us via either submit@scirp.org or Online Submission Portal.
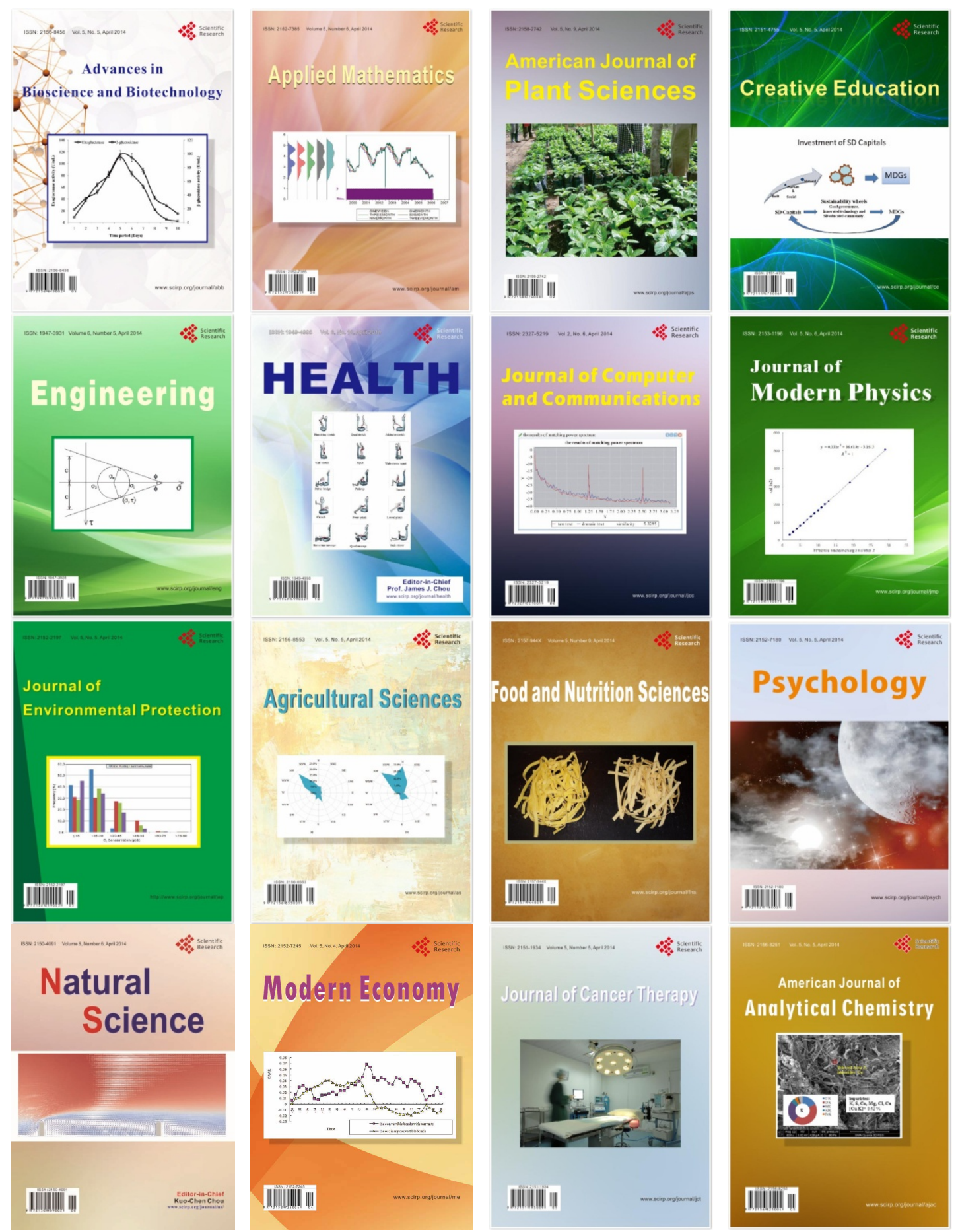